\title{
Intensitas Penggunaan Ruang Terbuka Komunal di Lingkungan Kampus Kota Makassar
}

\author{
* Citra Amalia Amal ${ }^{1}$, Andi Annisa Amalia ${ }^{1}$, Siti Fuadillah Alhumairah Amin ${ }^{1}$ \\ ${ }^{1}$ Prodi Arsitektur, Fakultas Teknik, Universitas Muhammadiyah Makassar, Indonesia; \\ Alamat Email: citraamaliaamal@unismuh.ac.id \\ *Alamat korespondensi, Masuk: 23 Mei 2019, Direvisi: 20 Jun. 2019, Diterima: 8 Jul. 2019
}

\begin{abstract}
ABSTRAK. Persentase jumlah dan luasan ruang-ruang terbuka komunal pada perguruan tinggi di Kota Makassar masih rendah, padahal ruang terbuka komunal di lingkungan kampus sering kali digunakan untuk media komunikasi informal, penunjang kegiatan kurikuler (diskusi, mengerjakan tugas, laporan atau makalah, serta tempat menunggu jeda kuliah). Keterbatasan ruang komunal di kampus tersebut akan berakibat pada terbentuknya ruang-ruang baru secara spontan, atau menggunakan ruang tidak sesuai fungsinya, sehingga menimbulkan konflik antar ruang, karena mahasiswa cenderung keluar dari batas teritori ruang yang sudah disiapkan di dalam kampus. Penelitian ini merupakan penelitian kuantitatif deskriptif. Teknik pengumpulan data yang digunakan adalah observasi dan angket (daftar pertanyaan). Intensitas penggunaan ruang terbuka komunal paling tinggi ditemukan pada area Taman Infinity Bridge Kampus Unhas, Pelataran Fakultas Teknik Industri Kampus UMI, area Taman Kampus UNM, dan Pelataran Balai Sidang Kampus Unismuh. Pada keempat ruang terbuka komunal tersebut terdapat interaksi sosial yang kontinu dalam durasi > 30 menit, dan pengalaman ruang yang menyenangkan. Adapun faktor-faktor yang mempengaruhi tingginya intensitas penggunaan ruang terbuka komunal pada keempat kampus di Kota Makassar, antara lain (1) Fasilitas untuk menunjang kenyamanan fisik berupa bangku taman atau tempat duduk dan gazebo, jogging track, jalur sepeda (2) View berupa danau, unsur soft scape (tanaman), atau mural (3) Kenyamanan sensory berupa ruang terbuka dengan adanya peneduh dan atap bangunan, (4) Aksesibilitas berupa pathway atau selasar yang dekat dengan ruang kuliah atau ruang tujuan berikutnya, (5) Keakraban dengan lingkungan, seperti teras masjid, selasar dan pelataran fakultas sangat dikenal oleh mahasiswa, (6) Estetika lingkungan berupa ikon tertentu yang dapat digunakan untuk berswafoto dan penataan tempat yang menarik.
\end{abstract}

Kata kunci: Komunal, kampus, intensitas, ruang terbuka, kontinu

\begin{abstract}
The percentage of the number and extent of communal open spaces in universities in Makassar is still low, whereas communal open spaces in the campus environment are often used for informal communication media, supporting curricular activities (discussions, doing assignments, reports or papers, and a place to wait for class breaks). The limited communal space on the campus will result in spontaneous formation of new spaces, or use of space that is not appropriate for its function, thereby causing conflicts between spaces, because students tend to get out of the territorial boundaries of space already prepared on campus. This research is a descriptive quantitative research. Data collection techniques used were observation and questionnaires (list of questions). The highest intensity of the use of communal open space was found in the Unhas Campus Infinity Bridge Park, the UMI Campus Industrial Engineering Court, the UNM Campus Park area, and the Unismuh Campus Convention Center Court. In the four communal open spaces there are continuous social interactions of $>30$ minutes duration, and pleasant space experiences. The factors that influence the high intensity of the use of communal open space on the four campuses in Makassar City include (1) facilities to support physical comfort in the form of park benches or seats and gazebos, jogging tracks, bicycle paths (2) View of lakes, elements of soft scape (plants), or murals (3) Sensory comfort in the form of open space in the presence of shade and roofs of buildings, (4) Accessibility in the form of pathways or corridors close to the lecture hall or the next destination, (5) Familiarity with the environment, such as the terrace of the mosque, the lobby and the court yard are well known to students, (6) Environmental aesthetics in the form of certain icons that can be used for selfies and interesting settings.
\end{abstract}

Keywords: Communal, campus, intensity, open space, continous 


\section{PENDAHULUAN}

Ruang publik atau ruang komunal menawarkan peluang untuk menarik interaksi sosial masyarakat. Bentuknya dalam bertemu masyarakat, saling mengenali, bertegur sapa, saling mengacuhkan satu sama lain atau bahkan konflik. Nilai-nilai sosial pada ruang publik didasarkan pada kontribusi dari masing-masing individu kepada ruang tersebut dan memungkinkan akumulasi beberapa individu serta memori individu tempat tersebut [1].

Pada masa lalu, studi konsep tentang ruang (terbuka) komunal fokus pada tingkatan keruangan, khususnya aksesibilitas visual dan fisik, bentuk dan ukuran serta pembatas ruang. Konsep terhadap ruang publik telah berganti seiring waktu. Ruang publik secara tradisional dapat berupa jalan raya, pasar, taman, tempat bermain dan lainnya. Saat ini fokus konsep ruang publik menuju ke arah aspek estetik dan proporsi ruang terbuka. Pada era modern, ruang publik ataupun ruang komunal dihasilkan sebagai alat untuk meningkatkan kualitas hidup. Lebih lanjut, konsep ruang publik juga merambah kepada ruangruang yang dimanfaatkan secara luas oleh masyarakat umum, namun dimiliki secara individu. Contohnya pusat perbelanjaan, restoran, dan kafe serta pusat penyelenggaraan pameran dan seni.

Mahasiswa adalah aktor utama yang akan menggunakan ruang publik di suatu perguruan tinggi disamping civitas akademik lainnya, seperti dosen, pegawai atau karyawan, maupun tenaga pendukung lainnya. Hal ini membawa dampak bahwa manusia sebagai pengguna ruang memiliki peran yang sangat besar dalam menentukan kualitas sebuah ruang. Kampus merupakan tempat utama mahasiswa melakukan berbagai macam aktivitas yang memiliki sarana berupa ruang-ruang berlangsungnya kegiatan formal dan informal bagi mahasiswa dan civitas akademik lainnya. Disamping ruang kelas sebagai sarana utama tempat belajar mahasiswa, sebuah kampus juga sudah selayaknya memiliki ruang terbuka sebagai tempat mahasiswa melakukan kegiatan informal. Kegiatan informal seperti berorganisasi atau berunit kegiatan, mengerjakan tugas kelompok, membuat acara kampus dan lain-lain akan turut membentuk karakter seorang mahasiswa. Selain itu, dengan mengikuti berbagai kegiatan informal di luar perkuliahan, diharapkan antar mahasiswa dapat berinteraksi dan bersosialisasi dengan sesamanya di luar ruang kelas dengan lebih baik dan memiliki pertemanan yang lebih erat.

Kebutuhan akan adanya ruang publik dalam kampus menjadi penting apabila dimaknai sebagai ruang yang berfungsi sebagai tempat interaksi sosial, menumbuhkan budaya demokrasi, aktualisasi diri, pengembangan akademik lainnya. Lingkungan kampus merupakan tempat dimana mahasiswa belajar untuk meraih masa depan yang lebih baik, idealnya tidak hanya bertujuan mengembangkan kognitif saja, melainkan juga bertujuan untuk mengembangkan kepribadian. Sehingga diperlukan wadah untuk menampung aktivitas-aktivitas tersebut. Sebagian besar kampus di Makassar hanya merancang ruang-ruang yang ditekankan pada aktivitas kurikuler di dalam ruangan/kelas, seperti ruang kuliah, laboratorium, praktikum, perpustakaan, aula dan sebagainya. Sebagian kecil lagi di antara kampus-kampus tersebut sudah menyiapkan wadah untuk aktivitas ekstra-kurikuler secara memadai. Pada hampir semua perguruan tinggi di Makassar persentase jumlah dan luasan ruang-ruang terbuka komunal masih rendah. Padahal ruang terbuka komunal di lingkungan kampus sering kali digunakan untuk media komunikasi informal, penunjang kegiatan kurikuler (diskusi, mengerjakan tugas, laporan atau makalah, serta tempat menunggu jeda kuliah).

Keterbatasan ruang komunal di kampus tersebut akan berakibat pada terbentuknya ruangruang baru secara spontan, atau menggunakan ruang tidak sesuai fungsinya, sehingga menimbulkan konflik antar ruang, karena mahasiswa cenderung keluar dari batas teritori ruang yang sudah disiapkan di dalam kampus. Selain itu, pemanfaatan ruang terbuka komunal di kampus selain sebagai ruang privat seharusnya juga dapat menjadi ruang komunal yang mengakomodir kepentingan publik dan relevan dalam pengembangan keilmuan, berkonfigurasi dengan aktivitas ruang sekitarnya dan menjadi batas teritori civitas akademik dalam melakukan kegiatan akademik baik formal maupun informal. Saat ini, beberapa kampus di Kota Makassar yang terletak pada jalur kolektor primer telah menyediakan ruang terbuka baik berupa jalur pedestrian, parkir, lapangan serta taman yang tersebar di dalam kampus, namun penggunanya didominasi dari kalangan kampus itu sendiri. Untuk itu, maka dilakukan penelitian mengenai intensitas penggunaan ruang terbuka komunal pada 
Perguruan Tinggi Negeri (PTN) yaitu kampus Universitas Hasanuddin (Unhas) dan Universitas Negeri Makassar (UN sedangkan pada Perguruan Tinggi Swasta (PTS) yaitu kampus Universitas Muslim Indonesia (UMI) dan Universitas Muhammadiyah Makassar (Unismuh).

\section{TINJAUAN PUSTAKA}

Klasifikasi ruang terbuka publik dapat bersifat privat seperti pada lokasi Pendidikan, komersial area, ataupun perumahan, dimana kampus merupakan sampel kota dalam skala kecil mewadahi ragam komunitas kampus untuk berinteraksi [2]. Proses pengendalian keberadaan ruang terbuka publik di kampus dipengaruhi oleh rasio populasi mahasiswa setiap fakultas, umumnya terbentuk pada pohon-pohon yang rindang, dimanfaatkan untuk kegiatan ekstra mahasiswa dan terbentuk oleh swadaya mereka sendiri [3].

Peran ruang komunal sebagai wadah aktivitas kesehatan, sosial dan ekonomi baik terencana maupun tidak terencana terdiri atas 4 parameter yaitu sifat kegiatan, frekuensi, jarak jangkauan, dan skala kegiatan [4]. Bangunan universitas harus memperhatikan kebutuhan sosiologis masyarakat semi urban atau urban karena mulai cenderung individualistis namun pada satu titik dapat menjadi crowd atau komunal [5].

Lokasi ruang komunal kampus tersebar di sekitar area Gedung Perkuliahan berupa Ruang Terbuka Hijau dijadikan sebagai ruang publik dan ruang belajar terbuka untuk kegiatan pembelajaran di luar kelas dan berpotensi menunjang fungsi ekonomi dengan menanam tanaman budidaya sehingga dapat menghasilkan tanaman atau buah yang dapat dikonsumsi atau dijual sebagai produk [6].

Kegiatan yang bersifat formal adalah kegiatan yang dilaksanakan berdasar jadwal (terstruktur) dan kegiatan tersebut dipimpin oleh dosen [7]. Kegiatan yang bersifat Informal yaitu kegiatan yang dilaksanakan atas dasar kesadaran sendiri, dan tanpa pemrakarsa. Termasuk dalam kegiatan ini adalah berbincang-bincang, menunggu kuliah, menunggu dosen, menunggu teman, berdiskusi, dan lain-lain. Lebih lanjut dinyatakan bahwa ruang yang dimanfaatkan oleh mahasiswa untuk melakukan kegiatan berinteraksi sosial karena adanya alasan sebagai berikut : (1) dekat dengan ruang yang dituju, (2) tempatnya teduh terletak dalam suatu bangunan, terhalang dari sinar matahari dan hujan secara langsung maupun tak langsung, dan terhalang angin keras, (3) tempat terbuka pada satu dinding atau satu sisi, (4) tempat yang kosong, (5) tempat yang digunakan untuk duduk dan nyaman secara ergonomik, (6) bebas, tidak terhalang apabila ingin melihat ke tempat parkir, (7) bebas, tidak terhalang melihat ke arah kehadiran dosen, dan (8) kemudahan mendapatkan informasi.

Ruang komunal (berasal dari kata communal yang berarti berhubungan dengan umum) merupakan ruang yang menampung kegiatan sosial dan digunakan oleh untuk seluruh masyarakat atau komunitas [8]. Lebih lanjut dikatakan bahwa ruang komunal memberikan kesempatan kepada masyarakat/orang untuk bertemu, tetapi untuk menjadikan hal ini diperlukan beberapa katalisator. Katalisator mungkin secara individu membawa orang secara bersama-sama dalam sebuah aktivitas, diskusi atau topik umum. Ruang komunal dapat berupa ruang terbuka dan ruang tertutup. Ruang terbuka pada dasarnya merupakan suatu lingkungan yang baik secara individu atau kelompok dapat digunakan oleh publik.

Ruang komunal yang ideal seharusnya memenuhi kriteria [9]: (1) image and identity, berdasarkan sejarahnya; (2) attraction and Destinations, memiliki tempat-tempat kecil yang didalamnya memiliki suatu daya tarik; (3) ketenangan (amenities, memiliki bentuk ketenangan yang membuat orang merasa nyaman); (4) flexible design, digunakan sepanjang hari, dari pagi, siang dan malam; (5) seasonal strategy, keberhasilan ruang terbuka bukan hanya fokus pada salah satu desain saja, atau pada strategi manajemennya, tetapi dengan memberikan tampilan berubah-ubah yang berbeda dari satu musim ke musim lainnya; (6) akses ruang terbuka memiliki kedekatan dan kemantapan aksesibilitas mudah dijangkau.

Tipologi ruang terbuka dapat diklasifikasikan sebagai berikut : (1) Ruang Terbuka Non Hijau berupa plaza, parkir, lapangan, tempat bermain dan rekreasi, pembatas dan koridor; (2) Ruang Terbuka Hijau secara fisik [10], fungsi, struktur ruang, dan kepemilikan.

Kelompok pengguna ruang komunal berdasarkan perkembangan manusia adalah hal-hal yang berhubungan dengan perkembangan manusia semenjak lahir sampai usia lanjut [11]. Sementara kelompok pemakai berdasarkan kelompok aktivitas tertentu adalah berkaitan dengan setting atau latar : (1) setting pendidikan yang digunakan kelompok pemakai tertentu dengan jenjang tertentu, misalnya ruang kelas, asrama, laboratorium, ruang terbuka 
dan perpustakaan; (2) setting perkantoran; (3) setting perumahan yang digunakan oleh kelompok pemakai tertentu, dapat berdasarkan kelas sosial, tingkat penghasilan, gaya hidup, dan sebagainya, bentuknya pun beragam seperti unit hunian tunggal, rumah susun, rumah kopel, apartemen, dan sebagainya.

Mahasiswa adalah masa periode dewasa awal (early adulthood) yang berkisar antara 18-40 tahun dianggap sebagai umur-umur pembentukan (formative years). Pada masa permulaan dewasa awal, sebagian diantaranya adalah mereka yang berkesempatan untuk belajar di perguruan tinggi. Lingkungan kampus menjadi tempat dimana mereka belajar untuk meraih masa depan yang lebih baik, idealnya tidak hanya bertujuan mengembangkan kognitif saja, melainkan juga bertujuan mengembangkan kepribadian [12].

Aksesibilitas, pendukung aktivitas, pengaturan dan kontrol, serta even-even temporer menjadi faktor penentu dalam intensitas penggunaan ruang komunal dalam suatu kampus [13]. Menurutnya, ruang-ruang dengan aksesibilitas tinggi juga memiliki intensitas penggunaan publik yang tinggi. Ruang-ruang terbentuk berbentuk koridor jalan menempati intensitas penggunaan tertinggi, meskipun didominasi oleh sirkulasi kendaraan. Aksesibilitas tidak terbatas pada akses fisik ruang yang dimaksud, akan tetapi termasuk akses visual. Pendukung aktivitas yang mendorong penggunaan ruang komunal adalah ketersediaan PKL, makanan, ketersediaan area parkir, peneduhan dan wi-fi spot. Selain itu perkerasan dan fasilitas lapangan olahraga juga mendukung penggunaan ruang untuk aktivitas olahraga. Selain itu, intervensi peraturan dan kontrol cukup dominan mempengaruhi tingkat penggunaan ruang komunal. Ruang-ruang yang aksesnya harus melewati pos penjagaan memiliki intensitas penggunaan publik lebih rendah dibanding yang tidak diberi penjagaan. Kemudian aktivitas lain yang mempengaruhi intensitas penggunaan ruang komunal adalah pada saat even-even temporer, terjadi peningkatan penggunaan ruang terbuka.

\section{METODE PENELITIAN}

Penelitian ini merupakan penelitian kuantitatif deskriptif. Teknik pengumpulan data yang digunakan adalah observasi dan angket (daftar pertanyaan).

\section{Lokasi Penelitian}

Lokasi penelitian ditetapkan pada empat kampus yaitu Universitas Hasanuddin (Unhas) Tamalanrea, Universitas Negeri Makassar (UNM) Parang Tambung, Universitas Muslim Indonesia (UMI), dan Universitas Muhammadiyah Makassar (Unismuh).

Ruang terbuka komunal yang diteliti dari keempat kampus di atas mengambil area taman, pelataran masjid atau pelataran fakultas. Pemilihan area ini didasarkan pada kriteria ruang yang sering dipakai atau intensitas penggunaannya tinggi dengan periode waktu penggunaan relatif teratur.

\section{Metode Pengumpulan Data}

Pengambilan data dilakukan melalui observasi/pengamatan dan wawancara tertutup. Observasi lapangan dilakukan untuk mendapatkan data perilaku dan data fisik spasial ruang. Untuk mendapatkan data perilaku pengguna ruang dilakukan dengan metode place centered mapping (pemetaan berdasarkan tempat). Observasi untuk mendapatkan data-data fisik dan spasial ruang komunal dengan mencatat, menggambar/sketsa kondisi fisik ruang komunal dan sekitarnya. Sedangkan untuk mendapatkan data yang berkaitan dengan intensitas penggunaan ruang komunal maka dilakukan wawancara tertutup pada responden serta pengamatan langsung di lapangan.

Observasi/pengamatan serta wawancara tertutup dilaksanakan dalam sepekan terdiri atas weekdays dan weekend. Waktu pengamatan terbagi dalam tiga zona waktu yaitu Pagi $(09.00-12.00)$, Siang $(12.01-15.00)$, dan Sore $(15.01-18.00)$.

\section{Metode Analisis Data}

Dalam analisis data, data disusun agar dapat ditafsirkan dengan cara menggolongkan dalam tema atau kategorisasi. Dalam penelitian ini akan dicari intensitas penggunaan ruang komunal kampus dari adanya variasi jumlah pengguna ruang, jenis kelamin, waktu penggunaan ruang, frekuensi dan alasan penggunaan ruang.

Frekuensi dan alasan penggunaan ruang terbuka komunal di lingkungan kampus berkaitan dengan apa yang pengguna inderakan atau rasakan dari keberadaan ruang komunal tersebut. Tentang bagaimana penghuni menginterpretasikan atau memberikan arti terhadap ruang-ruang komunal yang ada. Untuk mengetahui frekuensi dan alasan, ditentukan lima indikator yang sesuai dengan tujuan dan konteks penelitian. Kelima indikator tersebut yaitu luas, letak, sirkulasi udara, arah 
pandang (view), dan ketersediaan peralatan penunjang.

\section{HASIL DAN PEMBAHASAN \\ Intensitas Penggunaan Ruang Terbuka Komunal di Kampus Universitas Hasanuddin (Unhas)}

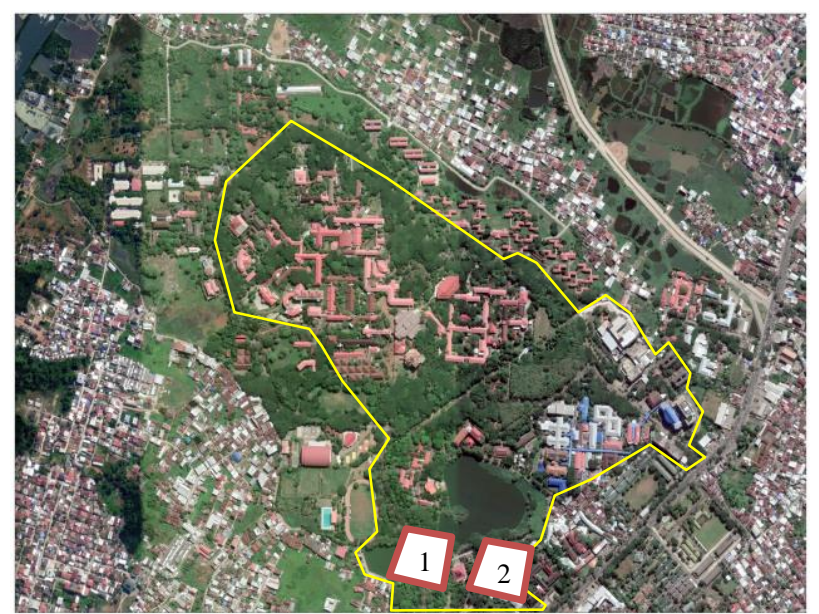

Gambar 1. Peta Lokasi Penelitian Unhas: (1) Taman Infinity Bridge dan (2) Masjid

Ruang publik yang menjadi lokasi penelitian di Kampus Unhas adalah pada bagian main entrance Pintu 1 yaitu Taman Infinity Bridge dan Masjid Kampus Unhas. Tempat ini letaknya pada sisi selatan kampus.
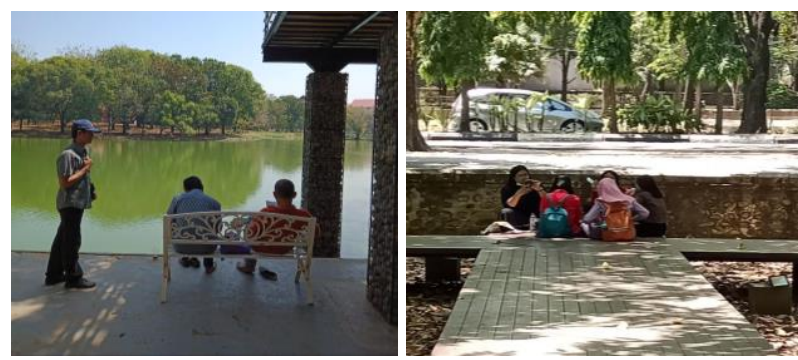

Gambar 2. Aktivitas bersantai di Pelataran Masjid Kampus Unhas (kiri) dan berkumpul di Taman Infinity Bridge (kanan)

Tabel 1. Intensitas Penggunaan Taman Infinity Bridge Unhas

\begin{tabular}{|c|c|c|c|}
\hline Waktu & Durasi & Jumlah & Jenis \\
\hline Pengamatan & Penggunaan & Pengguna & Kegiatan \\
\hline Pagi & $>30$ menit & 36 Orang & $\begin{array}{c}\text { Istirahat, } \\
\text { berkumpul, } \\
\text { makan, } \\
\text { memancing }\end{array}$ \\
\hline Siang & $>30$ menit & 65 Orang & $\begin{array}{c}\text { Berkumpul, } \\
\text { berdiskusi, } \\
\text { berinteraksi, } \\
\text { tidur dan }\end{array}$ \\
\hline
\end{tabular}

Sore $\quad>30$ menit $\quad 84$ Orang

makan

Berkumpul, berdiskusi, berinteraksi, berolahraga, makan

(Sumber: Analisis Hasil Penelitian, 2019)

Pada taman Infinity Bridge Kampus Unhas dimanfaatkan saat pagi, siang dan sore hari dengan durasi waktu rata-rata > 30 menit. Di taman ini terdapat fasilitas antara lain jogging track, sepeda, dan view danau yang ditunjang dengan pepohonan dengan tajuk sangat lebar, jembatan kayu yang terhubung satu sama lain, kursi taman, dan infinity bridge berbentuk lingkaran sehingga memudahkan pengunjung berkeliling menelusuri danau. Aktivitas yang dilakukan di taman cukup beragam mulai dari olahraga jogging dan bersepeda, makan sambil bersantai, beristirahat atau datang untuk berswafoto dan menikmati kenyamanan udara dan keindahan taman. Taman ini dapat diakses dengan mudah karena dilalui transportasi umum angkutan kota (angkot), sehingga pengunjung tidak hanya dari mahasiswa atau warga kampus saja. Semenjak beroperasinya infinifity bridge di taman ini, maka pengujung cukup banyak berdatangan meskipun hari libur karena mereka menjadikannya sebagai salah satu destinasi wisata baru di Makassar.

Tabel 2. Intensitas Penggunaan Pelataran Masjid

\begin{tabular}{|c|c|c|c|}
\hline $\begin{array}{c}\text { Waktu } \\
\text { Pengamatan }\end{array}$ & $\begin{array}{c}\text { Durasi } \\
\text { Penggunaan }\end{array}$ & $\begin{array}{l}\text { Jumlah } \\
\text { Pengguna }\end{array}$ & $\begin{array}{c}\text { Jenis } \\
\text { Kegiatan }\end{array}$ \\
\hline Pagi & $0-15$ menit & 12 Orang & Istirahat \\
\hline Siang & $0-30$ menit & 13 Orang & $\begin{array}{l}\text { Istirahat } \\
\text { dan } \\
\text { berkumpul }\end{array}$ \\
\hline Sore & $0-30$ menit & 24 Orang & $\begin{array}{l}\text { Menunggu } \\
\text { dan } \\
\text { berdiskusi }\end{array}$ \\
\hline
\end{tabular}

(Sumber: Analisis Hasil Penelitian, 2019)

Tabel 3. Persepsi Pengguna yang Mempengaruhi Intensitas Penggunaan Ruang Terbuka Komunal Kampus Universitas Hasanuddin

\begin{tabular}{ccc}
\hline No & $\begin{array}{c}\text { Variabel Ruang Terbuka } \\
\text { Komunal }\end{array}$ & $\begin{array}{c}\text { Nilai } \\
\text { Rata- } \\
\text { Rata }\end{array}$ \\
\hline 1 & Bersantai dan menikmati & 2,7 \\
waktu sendiri & \\
2 & $\begin{array}{c}\text { Memadai untuk berkumpul } \\
\text { dan berinteraksi }\end{array}$ & 2,9 \\
3 & Memadai untuk berolahraga & 2,7 \\
4 & $\begin{array}{c}\text { Mudah diakses dari Gedung } \\
\text { Fakultas }\end{array}$ & 2,6 \\
&
\end{tabular}




\begin{tabular}{|c|c|c|}
\hline 5 & Sirkulasi ruang & 2,9 \\
\hline 6 & $\begin{array}{l}\text { Ruang komunal karena } \\
\text { kondisinya bersih }\end{array}$ & 2,2 \\
\hline 7 & View mendukung & 2,8 \\
\hline 8 & $\begin{array}{l}\text { Peralatan penunjang berupa } \\
\text { tempat duduk }\end{array}$ & 2,9 \\
\hline 9 & $\begin{array}{l}\text { Peralatan penunjang berupa } \\
\text { pohon peneduh dan kanopi }\end{array}$ & 2,5 \\
\hline 10 & $\begin{array}{l}\text { Peralatan penunjang untuk } \\
\text { berdiskusi berupa gazebo }\end{array}$ & 2,3 \\
\hline 11 & $\begin{array}{c}\text { Tersedia Pedagang Kaki } \\
\text { Lima (PKL) }\end{array}$ & 1,4 \\
\hline 12 & Tersedia wifi spot & 1,3 \\
\hline
\end{tabular}

(Sumber: Analisis Hasil Penelitian, 2019)

Selain taman Unhas, Masjid Kampus juga menjadi ruang komunal karena tidak hanya digunakan oleh mahasiswa tetapi dari masyarakat sekitar yang akan melakukan ibadah atau ingin beristirahat di tempat tersebut karena area pelataran masjid cukup luas. Selain itu view cukup baik pada area ini, karena terdapat rumah kaca di bagian depan masjid dan view danau serta disediakannya bangku taman yang memudahkan pengunjung dapat menikmati alam danau sambil beristirahat.

\section{Intensitas Penggunaan Ruang Terbuka Komunal di Kampus Universitas Negeri Makassar (UNM) \\ Ruang komunal dalam lingkungan Kampus} UNM terkonsentrasi pada taman dan pelataran masjid. Mereka memanfaatkan ruang komunal untuk duduk, bersantai, menunggu dosen untuk kuliah berikutnya, mengerjakan tugas, berkumpul dan berinteraksi dengan sesama mahasiswa.

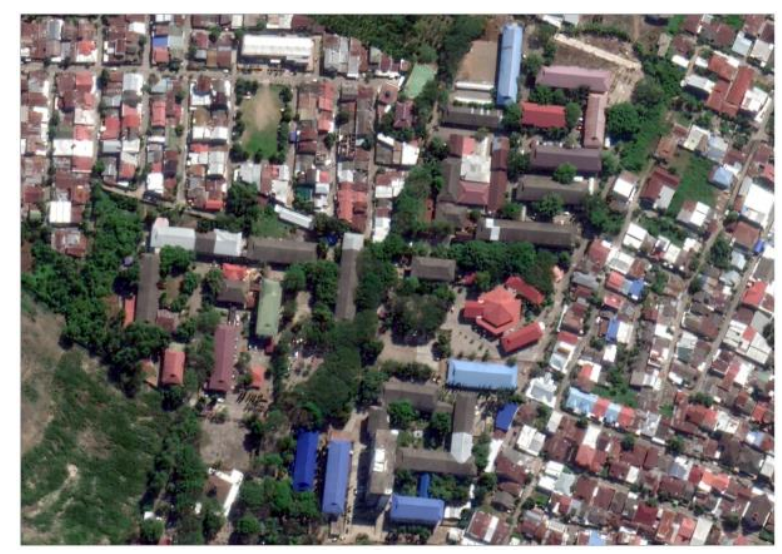

Gambar 3. Peta Lokasi Penelitian UNM: (1) Taman, (2) Pelataran Masjid

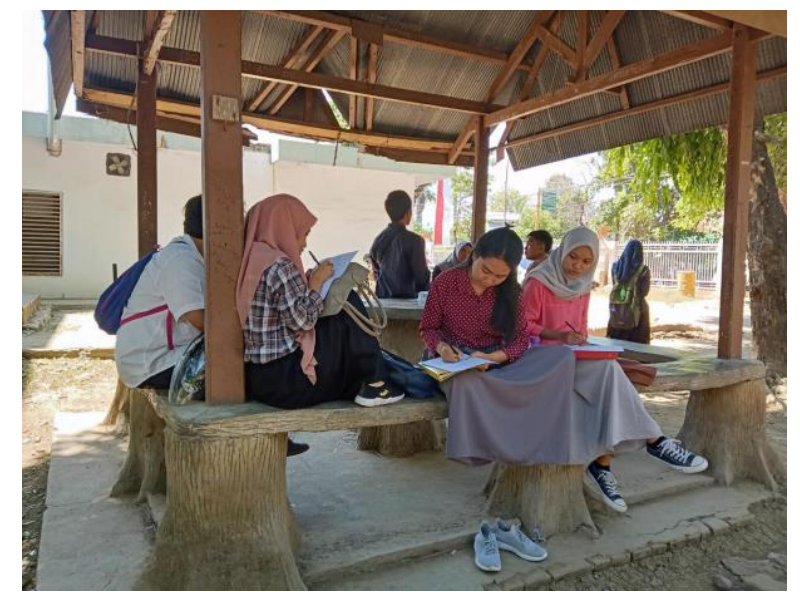

Gambar 4. Aktivitas di Taman UNM

Pengguna ruang komunal didominasi oleh mahasiswa. Ruang komunal yaitu ruang publik di lingkungan kampus yang ditempati secara bersama-sama oleh mahasiswa baik individu maupun berkelompok yang lebih banyak difungsikan informal di luar kegiatan utamanya (kuliah) misalnya di plaza, lobi, ruang-ruang duduk/sitting group, tangga, selasar, dan ruang informasi [7].

Tabel 4. Intensitas Penggunaan Taman

\begin{tabular}{|c|c|c|c|}
\hline Waktu & Durasi & Jumlah & Jenis \\
\hline Pengamatan & Penggunaan & Pengguna & Kegiatan \\
\hline Pagi & $>30$ menit & 49 Orang & $\begin{array}{c}\text { Berkumpul, } \\
\text { mengerjakan } \\
\text { tugas kuliah, } \\
\text { istirahat, } \\
\text { dan makan }\end{array}$ \\
\hline Siang & $16-30$ menit & 45 Orang & $\begin{array}{l}\text { Berkumpul, } \\
\text { berinteraksi }\end{array}$ \\
\hline Sore & 16-30 menit & 75 Orang & $\begin{array}{c}\text { Berdiskusi, } \\
\text { bersantai } \\
\text { dan } \\
\text { tongkrong }\end{array}$ \\
\hline
\end{tabular}

(Sumber: Analisis Hasil Penelitian, 2019)

Fasilitas pada taman terdapat tempat duduk terbuat dari beton berbentuk batang pohon, yang berada di bawah pohon dengan permukaan pelataran terbuat dari paving block. Intensitas penggunaan pada sore hari lebih banyak dibandingkan pada pagi maupun siang hari. Selain taman, pelataran masjid kampus juga digunakan mahasiswa untuk beraktivitas informal di luar jam kuliah karena terdapat gazebo sehingga mereka dapat beristirahat, berdiskusi dan mengerjakan tugas. 


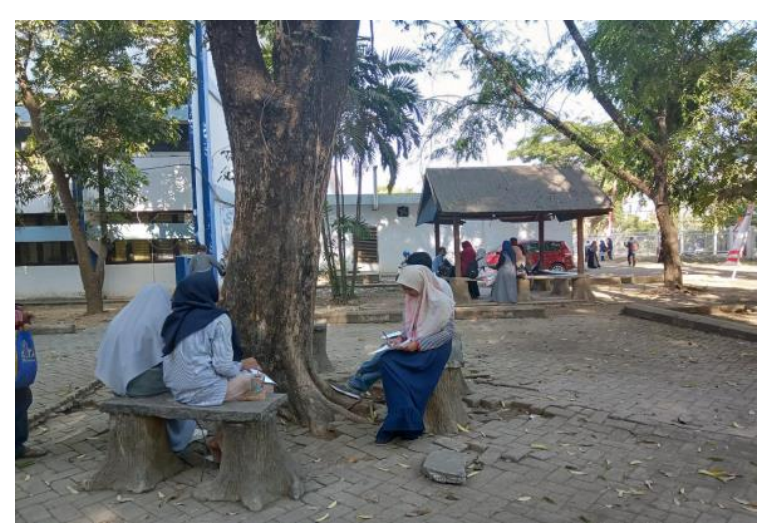

Gambar 5. Aktivitas di Pelataran Masjid UNM

Tabel 5. Intensitas Penggunaan Pelataran Masjid

\begin{tabular}{|c|c|c|c|}
\hline $\begin{array}{c}\text { Waktu } \\
\text { Pengamatan }\end{array}$ & $\begin{array}{c}\text { Durasi } \\
\text { Penggunaan }\end{array}$ & $\begin{array}{c}\text { Jumlah } \\
\text { Pengguna }\end{array}$ & $\begin{array}{c}\text { Jenis } \\
\text { Kegiatan }\end{array}$ \\
\hline Pagi & $16-30$ menit & 61 Orang & $\begin{array}{c}\text { Berkumpul, } \\
\text { berdiskusi } \\
\text { dan istirahat }\end{array}$ \\
\hline Siang & $>30$ menit & 44 Orang & $\begin{array}{l}\text { Berdiskusi, } \\
\text { mengerjakan } \\
\text { tugas }\end{array}$ \\
\hline Sore & $16-30$ menit & 48 orang & $\begin{array}{c}\text { Beristirahat } \\
\text { dan } \\
\text { berdiskusi }\end{array}$ \\
\hline
\end{tabular}

(Sumber: Analisis Hasil Penelitian, 2019)

Tabel 6. Persepsi Pengguna yang Mempengaruhi Intensitas Penggunaan Ruang Terbuka Komunal Kampus UNM

\begin{tabular}{|c|c|c|}
\hline No & $\begin{array}{c}\text { Variabel Ruang Terbuka } \\
\text { Komunal }\end{array}$ & $\begin{array}{c}\text { Nilai } \\
\text { Rata-Rata }\end{array}$ \\
\hline 1 & $\begin{array}{c}\text { Bersantai dan menikmati waktu } \\
\text { sendiri }\end{array}$ & 1,9 \\
\hline 2 & $\begin{array}{l}\text { Memadai untuk berkumpul dan } \\
\text { berinteraksi }\end{array}$ & 2,2 \\
\hline 3 & Memadai untuk berolahraga & 1,9 \\
\hline 4 & $\begin{array}{c}\text { Mudah diakses dari Gedung } \\
\text { Fakultas }\end{array}$ & 2,5 \\
\hline 5 & Sirkulasi ruang & 2,2 \\
\hline 6 & $\begin{array}{l}\text { Ruang komunal karena } \\
\text { kondisinya bersih }\end{array}$ & 1,9 \\
\hline 7 & View mendukung & 2,3 \\
\hline 8 & $\begin{array}{l}\text { Peralatan penunjang berupa } \\
\text { tempat duduk }\end{array}$ & 1,8 \\
\hline 9 & $\begin{array}{l}\text { Peralatan penunjang berupa } \\
\text { pohon peneduh dan kanopi }\end{array}$ & $\begin{array}{l}2,2 \\
2,0\end{array}$ \\
\hline 10 & $\begin{array}{l}\text { Peralatan penunjang untuk } \\
\text { berdiskusi berupa gazebo }\end{array}$ & 2,0 \\
\hline 11 & $\begin{array}{l}\text { Tersedia Pedagang Kaki Lima } \\
\text { (PKL) }\end{array}$ & 2,0 \\
\hline 12 & Tersedia wifi spot & 1,6 \\
\hline
\end{tabular}

(Sumber: Analisis Hasil Penelitian, 2019)
Berdasarkan pengamatan di lapangan, dapat diketahui bahwa karakteristik dari ruang komunal yang cenderung dimanfaatkan mahasiswa di UNM adalah dekat dengan ruang kuliah, tempat terbuka, tempat kosong, tempat yang teduh, dan tempatnya luas untuk berkumpul.

\section{Intensitas Penggunaan Ruang Terbuka Komunal di Kampus Universitas Muslim Indonesia (UMI)}

Ruang komunal yang berlokasi di Kampus UMI merupakan bagian dari ruang komunal seperti teras, pelataran Masjid dan Fakultas. Salah satu teras fakultas yang dimanfaatkan oleh mahasiswa kampus adalah teras Fakultas Teknik Industri tepatnya di pelataran Cabin Canteen. Tempat ini letaknya berada di tengah gedung perkuliahan Kampus UMI.

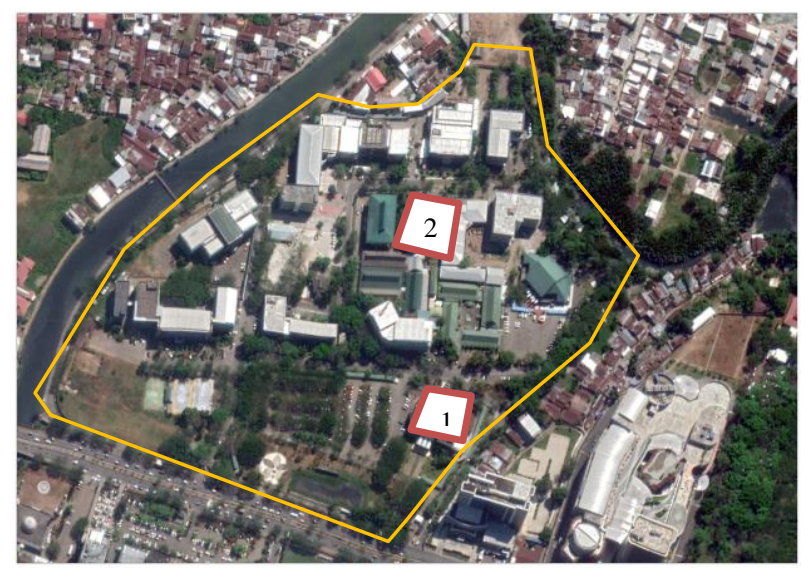

Gambar 6. Peta Lokasi Penelitian UMI: (1) Pelataran Fakultas Teknik Industri (2) Pelataran Masjid

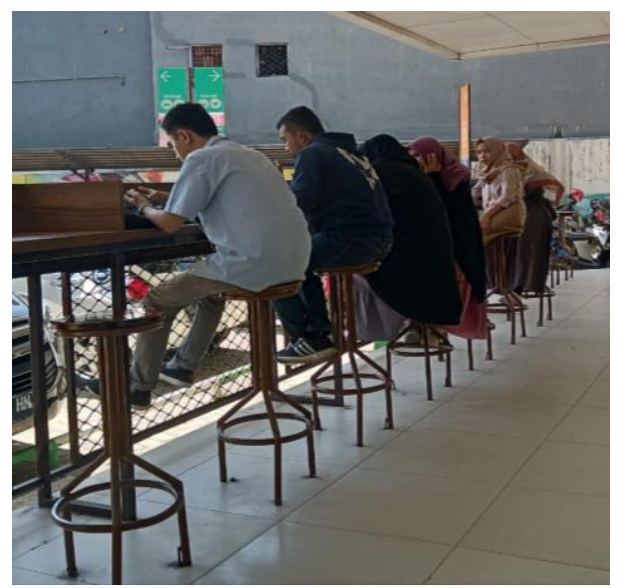

Gambar 7. Aktivitas Ruang Terbuka di Pelataran Cabin Canteen Fakultas Teknik Industri 


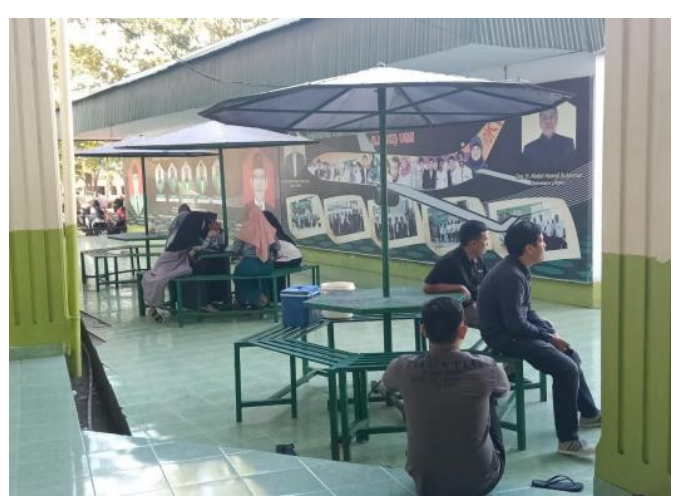

Gambar 8. Aktivitas Beristirahat di Selasar Masjid

Pengguna ruang komunal adalah mahasiswa, ruang pada area masjid yang digunakan adalah selasar menuju ke ruang wudu dan akses ke lantai 2 karena di tempat tersebut terdapat peneduh berupa kanopi dan tempat duduk sitting group. Sehingga banyak mahasiswa yang menggunakannya untuk makan, beristirahat sambil menunggu waktu Shalat. Selain itu, teras masjid juga digunakan untuk berdiskusi dan beristirahat.

Pengguna mahasiswa lebih banyak di kedua area ini karena letaknya mudah diakses dari gedung kuliah dan luas. Pada pelataran Fakultas Teknik Industri, adanya beberapa tempat untuk berswafoto seperti kabin, mural berbentuk 3 dimensi dan dekat dengan kantin menjadi alasan mahasiswa menjadikan tempat ini sebagai ruang berkumpul, berdiskusi dan tongkrong serta makan terutama pada siang hari di luar jam kuliah. Sedangkan pada pelataran masjid digunakan untuk berdiskusi, makan dan istirahat karena pada area ini terdapat PKL seperti penjual bakso dan minuman dingin, dekat dari ruang parkir, lokasinya terbuka dan terdapat peneduh seperti kanopi dan pepohonan.

Tabel 7. Intensitas Penggunaan Teras dan Pelataran Fakultas Teknik Industri

\begin{tabular}{cccc}
\hline $\begin{array}{c}\text { Waktu } \\
\text { Pengamatan }\end{array}$ & $\begin{array}{c}\text { Durasi } \\
\text { Penggunaan }\end{array}$ & $\begin{array}{c}\text { Jumlah } \\
\text { Pengguna }\end{array}$ & $\begin{array}{c}\text { Jenis } \\
\text { Kegiatan }\end{array}$ \\
\hline Pagi & $>30$ menit & 39 Orang & $\begin{array}{c}\text { Berkumpul, } \\
\text { berdiskusi, } \\
\text { makan }\end{array}$ \\
Siang & $>30$ menit & 82 Orang & $\begin{array}{c}\text { Berkumpul, } \\
\text { berdiskusi, } \\
\text { berinteraksi } \\
\text { tongkrong } \\
\text { Berkumpul, } \\
\text { berdiskusi, }\end{array}$ \\
\hline
\end{tabular}

berinteraksi tongkrong, makan

(Sumber: Analisis Hasil Penelitian, 2019)

Tabel 8. Intensitas Penggunaan Pelataran Masjid

\begin{tabular}{|c|c|c|c|}
\hline $\begin{array}{c}\text { Waktu } \\
\text { Pengamatan }\end{array}$ & $\begin{array}{c}\text { Durasi } \\
\text { Penggunaan }\end{array}$ & $\begin{array}{c}\text { Jumlah } \\
\text { Pengguna }\end{array}$ & $\begin{array}{c}\text { Jenis } \\
\text { Kegiatan }\end{array}$ \\
\hline Pagi & $>30$ menit & $\begin{array}{c}110 \\
\text { Orang }\end{array}$ & $\begin{array}{c}\text { Berdiskusi } \\
\text { dan } \\
\text { beristirahat }\end{array}$ \\
\hline Siang & $>30$ menit & 72 Orang & $\begin{array}{c}\text { Berdiskusi } \\
\text { dan } \\
\text { beristirahat }\end{array}$ \\
\hline Sore & $0-15$ menit & 34 Orang & $\begin{array}{c}\text { Beristirahat, } \\
\text { makan dan } \\
\text { berdiskusi }\end{array}$ \\
\hline
\end{tabular}

(Sumber: Analisis Hasil Penelitian, 2019)

Tabel 9. Persepsi Pengguna yang Mempengaruhi Intensitas Penggunaan Ruang Terbuka Komunal Kampus UMI

\begin{tabular}{|c|c|c|}
\hline No. & $\begin{array}{c}\text { Variabel Ruang Terbuka } \\
\text { Komunal }\end{array}$ & $\begin{array}{l}\text { Nilai Rata- } \\
\text { Rata }\end{array}$ \\
\hline 1 & $\begin{array}{l}\text { Bersantai dan menikmati } \\
\text { waktu sendiri }\end{array}$ & 2,5 \\
\hline 2 & $\begin{array}{c}\text { Memadai untuk berkumpul } \\
\text { dan berinteraksi }\end{array}$ & 2,4 \\
\hline 3 & $\begin{array}{l}\text { Memadai untuk } \\
\text { berolahraga }\end{array}$ & 1,4 \\
\hline 4 & $\begin{array}{c}\text { Mudah diakses dari Gedung } \\
\text { Fakultas }\end{array}$ & 2,8 \\
\hline 5 & Sirkulasi ruang & 2,6 \\
\hline 6 & $\begin{array}{l}\text { Ruang komunal karena } \\
\text { kondisinya bersih }\end{array}$ & 2,5 \\
\hline 7 & View mendukung & 2,2 \\
\hline 8 & $\begin{array}{l}\text { Peralatan penunjang berupa } \\
\text { tempat duduk }\end{array}$ & 2,8 \\
\hline 9 & $\begin{array}{l}\text { Peralatan penunjang berupa } \\
\text { pohon peneduh dan kanopi }\end{array}$ & 2,8 \\
\hline 10 & $\begin{array}{l}\text { Peralatan penunjang untuk } \\
\text { berdiskusi berupa gazebo }\end{array}$ & 2,4 \\
\hline 11 & $\begin{array}{l}\text { Tersedia Pedagang Kaki } \\
\text { Lima (PKL) }\end{array}$ & 2,0 \\
\hline 12 & Tersedia wifi spot & 2,2 \\
\hline (Suml & alisis Hasil Penelitian, 2019) & \\
\hline
\end{tabular}

Ruang terbuka yang menjadi tempat pengamatan di Kampus Unismuh diantaranya adalah Pelataran Gedung Balai Sidang, Selasar Menara Iqra dan Pelataran Rektorat Lama. 


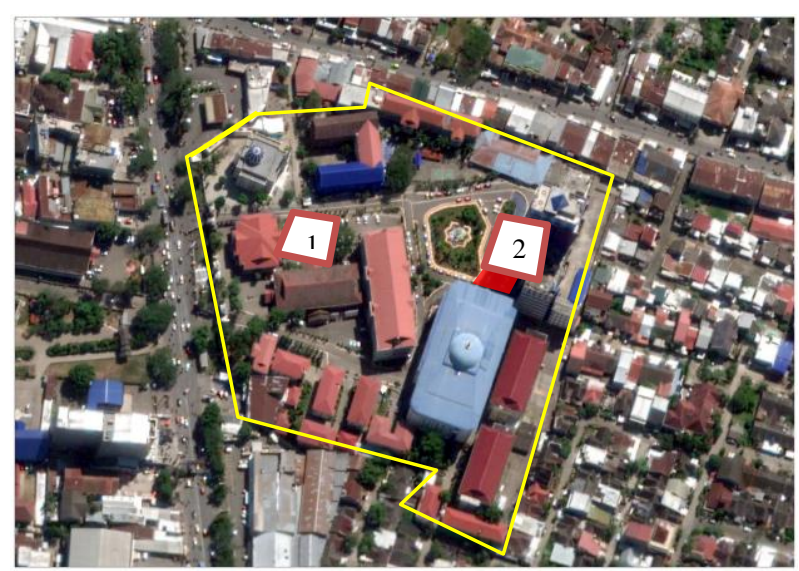

Gambar 8. Peta Lokasi Ruang Komunal Unismuh: (1) Pelataran Rektorat Lama, (2) Pelataran Gedung Balai Sidang dan Selasar Gedung Menara Iqra

Hal ini karena Pelataran Balai Sidang Unismuh letaknya cukup strategis dekat dari ruang kuliah mahasiswa di Gedung Menara Iqra, mudah diakses dari parkiran dan Students Mall (Kantin) dan ATM Centre. Selain itu, terdapat view cukup baik dengan adanya plaza air mencor dan berbentuk lingkaran dan dikelilingi oleh jalur pedestrian. Sedangkan pada Pelataran Gedung Rektorat Lama, digunakan sebagai tempat transit, dekat dari tempat parkir, akses menuju pintu keluar, perpustakaan dan Masjid. Berdasarkan hasil pengamatan, pengguna lebih banyak dari mahasiswa dan sebagian kecil dari dosen. Aktivitas komunal lebih terkonsentrasi pada Pelataran Balai Sidang dan Selasar Menara Iqra.

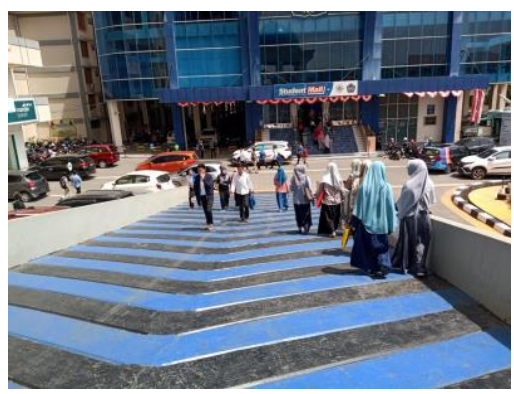

Gambar 8. Aktivitas Komunal di Pelataran Balai Sidang

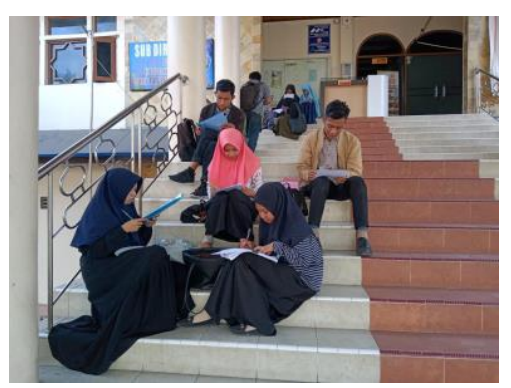

Gambar 9. Aktivitas di Pelataran Balai Sidang (kiri) dan Pelataran Rektorat Lama

Tabel 10. Intensitas Penggunaan Pelataran Balai Sidang dan Selasar Rektorat Lama

\begin{tabular}{|c|c|c|c|}
\hline $\begin{array}{c}\text { Waktu } \\
\text { Pengamatan }\end{array}$ & $\begin{array}{c}\text { Durasi } \\
\text { Penggunaan }\end{array}$ & $\begin{array}{c}\text { Jumlah } \\
\text { Pengguna }\end{array}$ & $\begin{array}{c}\text { Jenis } \\
\text { Kegiatan }\end{array}$ \\
\hline Pagi & $16-30$ menit & 78 Orang & $\begin{array}{l}\text { Berkumpul, } \\
\text { berdiskusi, } \\
\text { beristirahat } \\
\text { dan makan }\end{array}$ \\
\hline Siang & $16-30$ menit & 79 Orang & $\begin{array}{l}\text { Berkumpul, } \\
\text { berdiskusi, } \\
\text { Beristirahat } \\
\text { dan makan }\end{array}$ \\
\hline Sore & $16-30$ menit & 51 Orang & $\begin{array}{c}\text { Berdiskusi, } \\
\text { bersantai } \\
\text { dan } \\
\text { tongkrong }\end{array}$ \\
\hline
\end{tabular}

(Sumber: Analisis Hasil Penelitian, 2019)

Tabel 11. Intensitas Penggunaan Pelataran Rektorat Lama

\begin{tabular}{cccc}
\hline $\begin{array}{c}\text { Waktu } \\
\text { Pengamatan }\end{array}$ & $\begin{array}{c}\text { Durasi } \\
\text { Penggunaan }\end{array}$ & $\begin{array}{c}\text { Jumlah } \\
\text { Pengguna }\end{array}$ & $\begin{array}{c}\text { Jenis } \\
\text { Kegiatan }\end{array}$ \\
\hline Pagi & $0-15$ menit & 41 Orang & $\begin{array}{c}\text { Bersantai, } \\
\text { menunggu } \\
\text { dan } \\
\text { beristirahat }\end{array}$ \\
Siang & $16-30$ menit & 42 Orang & $\begin{array}{c}\text { Berdiskusi, } \\
\text { beristirahat } \\
\text { dan }\end{array}$ \\
Sore & $16-30$ menit & 41 Orang & $\begin{array}{c}\text { Menunggu } \\
\text { bengu, } \\
\text { berdiskusi } \\
\text { dan } \\
\text { bersantai }\end{array}$ \\
\hline
\end{tabular}

(Sumber: Analisis Hasil Penelitian, 2019)

Tabel 12. Persepsi Pengguna yang Mempengaruhi Intensitas Penggunaan Ruang Terbuka Komunal Kampus Unismuh

\begin{tabular}{ccc}
\hline No. & $\begin{array}{c}\text { Variabel Ruang Terbuka } \\
\text { Komunal }\end{array}$ & $\begin{array}{c}\text { Nilai } \\
\text { Rata- } \\
\text { Rata }\end{array}$ \\
\hline 1 & Bersantai dan menikmati \\
waktu sendiri & 2,2 \\
2 & $\begin{array}{c}\text { Memadai untuk berkumpul } \\
\text { dan berinteraksi }\end{array}$ & 2,3 \\
3 & Memadai untuk berolahraga & 1,6 \\
4 & Mudah diakses dari Gedung & 2,2 \\
& $\quad$ Fakultas \\
5 & $\quad$ Sirkulasi ruang \\
6 & Ruang komunal karena & 2,4 \\
7 & $\quad$ kondisinya bersih & 2,2 \\
8 & View mendukung & 1,5 \\
& Peralatan penunjang berupa & 1,9
\end{tabular}




\begin{tabular}{ccc} 
tempat duduk & \\
9 & $\begin{array}{c}\text { Peralatan penunjang berupa } \\
\text { pohon peneduh dan kanopi }\end{array}$ & 1,7 \\
10 & $\begin{array}{c}\text { Peralatan penunjang untuk } \\
\text { berdiskusi berupa gazebo } \\
\text { Tersedia Pedagang Kaki } \\
\text { Lima (PKL) }\end{array}$ & 1,7 \\
$11 \quad$ Tersedia wifi spot & 2,1 \\
12 & 1,7 \\
\hline (Sumber: Analisis Hasil Penelitian, 2019)
\end{tabular}

\section{KESIMPULAN}

Berdasarkan hasil analisis dan pembahasan, maka dapat disimpulkan bahwa intensitas penggunaan ruang terbuka komunal pada empat kampus di Kota Makassar sangat tinggi, ditinjau dari jumlah pengguna, durasi yang digunakan, serta jenis kegiatan yang dilakukan. Intensitas penggunaan ruang terbuka komunal paling tinggi ditemukan pada area Taman Infinity Bridge Kampus Unhas, Pelataran Fakultas Teknik Industri Kampus UMI, area Taman Kampus UNM, dan Pelataran Balai Sidang Kampus Unismuh. Pada keempat ruang terbuka komunal tersebut terdapat interaksi sosial yang kontinu dalam durasi > 30 menit, dan pengalaman ruang yang menyenangkan. Hal ini sesuai dengan teori bahwa pengalaman ruang dibentuk melalui visual space (terbentuk dari persepsi indra mata), audial space (terbentuk dari persepsi indra pendengaran), olfactual space (terbentuk dari persepsi indra penciuman), thermal space (terbentuk dari persepsi terhadap temperatur lingkungan), tectile space (terbentuk dari persepsi indra peraba dan kemampuan meraba), dan kinesthetic space (terbentuk dari batas-batas keleluasaan gerak manusia).

Adapun faktor-faktor yang mempengaruhi tingginya intensitas penggunaan ruang terbuka komunal pada keempat kampus di Kota Makassar, antara lain (1) fasilitas untuk menunjang kenyamanan fisik berupa bangku taman atau tempat duduk dan gazebo, jogging track, jalur sepeda (2) View berupa danau, unsur soft scape (tanaman), atau mural (3) Kenyamanan sensory berupa ruang terbuka dengan adanya peneduh dan atap bangunan, (4) Aksesibilitas berupa pathway atau selasar yang dekat dengan ruang kuliah atau ruang tujuan berikutnya, (5) Keakraban dengan lingkungan, seperti teras masjid, selasar dan pelataran fakultas sangat dikenal oleh mahasiswa, (6) Estetika lingkungan berupa ikon tertentu yang dapat digunakan untuk berswafoto dan penataan tempat yang menarik.

\section{UCAPAN TERIMA KASIH}

Tim Peneliti mengucapkan terima kasih kepada Universitas Muhammadiyah Makassar atas bantuan pendanaan yang diberikan sehingga penelitian dengan judul Intensitas Penggunaan Ruang Terbuka Komunal di Lingkungan Kampus Kota Makassar ini dapat terlaksana.

\section{DAFTAR PUSTAKA}

[1] Purnomo, Lubis, Nurhamsyah, dkk. (2019) Konsep Ruang Terbuka Publik Mahasiswa sebagai Penghubung Antar Unit di Universitas TanjungPura. Jurnal Langkau Betang Vol 1, No. 1:hal 1-3.

[2] Kustianingrum D, Virdianti E, Permata DD (2018) Sustainable Site: Kenyamanan Spasial pada Ruang Terbuka Publik Kampus Itenas Bandung. Jurnal Rekayasa Hijau, Vol. 2, No.2: hal 191-202.

[3] Syaifullah, Radiles H (2018) Pola Bauran Mahasiswa dalam Pemanfaatan Ruang Publik Terbuka Kampus. Jurnal Ilmiah Rekayasa dan Manajemen Sistem Informasi, Vol 4, No.2: hal 130-137.

[4] Tamariska SR, et.al. (2019) Peran Ruang Komunal dalam Menciptakan Sense of Community Studi Komparasi Perumahan Terencana dan Perumahan Tidak Terencana. Jurnal Koridor: Jurnal Arsitektur dan Perkotaan, Vol. 10, No.1: hal 65-73.

[5] Zailani M (2018) Persepsi Civitas Akademik pada Kenyamanan Tata Ruang Kampus UINSU Medan (Pendekatan Sosiologi Agama dan Transdisiplin Keilmuan). STUDIA SOSIA RELIGIA, Vol. 1, No.2: hal 10-24.

[6] Suciyani WO (2018) Analisis Potensi Pemanfaatan Ruang Terbuka Hijau (RTH) Kampus di Politeknik Negeri Bandung. Jurnal Planologi, Vol. 15, No. 1: hal 17-33.

[7] Wijayanti, Susi (2000) Pola Setting Ruang Komunal Interaksi Sosial Mahasiswa (Kasus Jurusan Arsitektur Fakultas Teknik UNDIP). Semarang: Universitas Diponegoro.

[8] Soepratikno (2004). Hubungan Ruang Komunal Persepsi Mahasiswa terhadap Setting Ruang Teras Utama Gedung A Jurusan Arsitektur Fakultas Teknik Universitas Diponegoro Semarang. Tesis Program Pascasarjana Universitas Diponegoro Semarang. Semaran: Universitas Diponegoro.

[9] Siahaan, James (2010). Ruang Publik: Antara Harapan dan Kenyataan. Buletin Tata Ruang, Edisi IV Juni Juli:11-16. Jakarta: Badan Koordinasi Penataan Ruang Nasional.

[10] Peraturan Menteri Pekerjaan Umum Nomor 12 /PRT/M/2009. Pedoman Penyediaan dan Pemanfaatan Ruang Terbuka Non Hijau di Wilayah Kota/Kawasan Perkotaan.

[11] Peraturan Menteri Pekerjaan Umum Nomor 05/PRT/M/2008. Pedoman Penyediaan Ruang Terbuka Hijau di Kawasan Perkotaan. 
[12] Prabowo, Hendro. 2010. Arsitektur, Psikologi dan Masyarakat. Seri Diktat Kuliah Universitas Gunadarma. Jakarta: Universitas Gunadarma.

[13] Sunaryo Rony (2015). Perubahan Setting Ruang dan Pola Aktivitas Publik di Ruang Terbuka Kampus UGM. Seminar Nasional Riset Arsitektur dan Perencanaan (SERAP 1), Humanisme, Arsitektur, dan Perencanaan. Surabaya: Universitas Kristen Petra.

(C) 2019 the Author(s), licensee Jurnal LINEARS. This is an open-access article distributed under the terms of the Creative Commons Attribution License

(http://creativecommons.org/licenses/by/4.0) 